\title{
Nitrogen Immobilization by Congo Grass Roots Impairs Cotton Initial Growth
}

\author{
Ciro A. Rosolem ${ }^{1}$, Fábio Steiner ${ }^{1}$, Samuel M. Zoca ${ }^{1}$, Carlos Ducatti ${ }^{2}$ \\ ${ }^{1}$ College of Agricultural Sciences, São Paulo State University, Botucatu, Brazil \\ ${ }^{2}$ Stable Isotopes Center, São Paulo State University, Botucatu, Brazil \\ Correspondence: Ciro A. Rosolem, São Paulo State University, College of Agricultural Sciences, Dep. of Crop \\ Science, C. P. 237, 18603-970 Botucatu SP, Brazil. Tel: 55-14-3880-7565. E-mail: rosolem@fca.unesp.br
}

Received: May 25, 2012 Accepted: June 15, 2012 Online Published: July 26, 2012

doi:10.5539/jas.v4n9p126 URL: http://dx.doi.org/10.5539/jas.v4n9p126

\begin{abstract}
In crop-livestock integration systems the presence of both grass roots in the soil and straw on the surface can temporarily immobilize nitrogen. This study examined the persistence of grass residues in the system as well as their effects on cotton response to $\mathrm{N}$ when grown after Congo grass (Brachiaria ruziziensis, Syn. Urochloa ruziziensis). Congo grass was grown in pots with soil. Next, cotton was grown in the same pots without residues, with whole plant residues (Congo grass roots and shoots) or root residues (grass roots) and fertilized with $\mathrm{N}$ as ammonium nitrate. Congo grass and cotton roots were separated using stable carbon isotope fractioning. Congo grass roots showed higher $\mathrm{C} / \mathrm{N}$ ratio than shoots, losing $14 \%$ of its mass after 45 days and increasing soil $\mathrm{N}$ immobilization. The lower $\mathrm{N}$ availability resulted in $\mathrm{N}$ deficient and shorter cotton plants with lower dry matter yields. Nevertheless, the application of 80 to $120 \mathrm{mg} \mathrm{kg}^{-1}$ of $\mathrm{N}$ compensated the immobilization by the soil microorganisms, allowing cotton to show normal growth. When Congo grass is present in the cropping system, the effects of the decaying roots on soil $\mathrm{N}$ dynamics and availability are more important than those of the straw left on the soil surface.
\end{abstract}

Keywords: Brachiaria ruziziensis, Gossypium hirsutum, nitrogen fertilization, roots, soil N dynamics

\section{Introduction}

Cotton can be grown in crop-livestock integration systems under no-till, which may result in increased soil productivity and quality, mainly in tropical regions. Among the cover crops used in crop-livestock integration systems forage grasses of the genus Brachiaria spp. are widely used because of their high biomass yield (Rezende et al., 1999), persistent straw, vigorous, deep root systems and their efficiency in suppressing weeds (Correia, Centurion, \& Alves, 2005). However, cover crops with high $\mathrm{C} / \mathrm{N}$ ratio in both shoots and roots, may impair growth and development of the subsequent crop (Silva \& Rosolem, 2001; Rosolem, Pace, \& Crusciol, 2004) mainly due to a temporary immobilization of the soil and fertilizer nitrogen $(\mathrm{N})$. Nitrogen immobilization after addition of plant residues to soil may last a few months, but it is more intense in the initial days. The $\mathrm{C} / \mathrm{N}$ ratio has been most widely used in models for predicting $\mathrm{N}$ availability during plant residue decay (Nicolardot, Recous, \& Mary, 2001). When the residues have $\mathrm{C} / \mathrm{N}$ ratios around 25 (pl. check its 20 or 25), there is a balance between N mineralization and immobilization (Allison, 1966). Trinsoutrot et al. (2000) applied 47 kinds of plant residues to soil and observed that net $\mathrm{N}$ mineralization occurred only in two of them within a 168-day period, both with $\mathrm{C} / \mathrm{N}$ ratios lower than 24 .

Nitrogen is the nutrient most required by cotton, as around 60 to $80 \mathrm{~kg}$ of $\mathrm{N}$ is utilized for each ton of seed-cotton produced. However, generally the soil available $\mathrm{N}$ is insufficient to meet the plant demand, and $\mathrm{N}$ fertilizer application is required. Nevertheless, when cotton is grown in rotation with grasses, $\mathrm{N}$ management in the soil-plant-straw system is difficult due to the dynamics of mineralization, leaching, volatilization, de-nitrification and crop uptake. Soybean growth was decreased when cropped after Ghinea sorghum (Olibone, Calonego, Pavinato, \& Rosolem, 2006), and cotton dry matter yields decreased up to $79 \%$ with the incorporation of signal grass (Brachiaria decubens) residues with a $\mathrm{C} / \mathrm{N}$ ratio of 44 into the soil (Souza, Velini, Martins, \& Rosolem, 2006). These authors observed also that the presence of Congo grass (B. ruziziensis) residues in the soil during cotton cultivation resulted in lower growth and lower root and shoot dry matter yields, as well as lower $\mathrm{N}$ uptake. Hence, soil microorganisms may compete for plant available $\mathrm{N}$ during Congo grass decomposition, rendering $\mathrm{N}$ unavailable for cotton during its initial growth. 
In humid tropical regions litter decomposition is rapid on the soil surface (Rezende et al., 1999), but mineralization of root $C$ is significantly lower than that of leaves and stems. It has been estimated that over $50 \%$ of the B. decumbens and B. ruziziensis root carbon would not be decomposed for a long time (Urquiaga, Cadish, Alves, Boddey, \& Giller, 1998; Abiven, Recous, Reyes, \& Oliver, 2005). Therefore, grass roots may play an important role in soil $\mathrm{N}$ immobilization and mineralization, and eventually affect soil $\mathrm{N}$ availability. However, in studies involving crop rotations, either in the field or greenhouses, it is difficult to separate the root system of the plants under study from non-decomposed roots from the previous cover crop, making it difficult to establish cause-effect relationships from the roots sampled as a whole. In general, due to the impossibility of manually sorting the roots from each species, all are taken as belonging to the main species, which may lead to incorrect interpretations. Plants bearing the $\mathrm{C} 3$ (herewith, cotton), and $\mathrm{C} 4$ (Congo grass) pathways of carbon assimilation have distinct values of $\delta{ }^{13} \mathrm{C}$, which are not overlapping (Boutton, 1991). Hence, tissues from plants with C3 and $\mathrm{C} 4$ pathways can be separated by fractioning the carbon $(\mathrm{C})$ stable isotope $\left(\delta{ }^{13} \mathrm{C}\right)$. This method has been successfully used in research for distinct objectives, however, no reports were found quantifying the proportion of $\mathrm{C} 3$ and $\mathrm{C} 4$ plant roots in cropping systems, and it is important to know the amount of decaying roots because they compete for the soil $\mathrm{N}$.

Considering that the competition for soil $\mathrm{N}$ will be higher with high amounts of grass roots and the long decaying process, the objective of this study was to evaluate the effect of $\mathrm{N}$ application and the presence of Congo grass residues on soil $\mathrm{N}$ dynamics and cotton growth.

\section{Materials and Methods}

An experiment was conducted in a greenhouse in Botucatu, SP, Brazil, $22^{\circ} 51^{\prime} \mathrm{S}, 48^{\circ} 26^{\prime} \mathrm{W}$, and $770 \mathrm{~m}$ altitude, in $8 \mathrm{~L}$ plastic pots. The soil was a Rhodic Hapludox (Soil Survey Staff, 2010) with $620 \mathrm{~g} \mathrm{~kg}^{-1}$ of sand, $70 \mathrm{~g} \mathrm{~kg}^{-1}$ of silt and $310 \mathrm{~g} \mathrm{~kg}^{-1}$ of clay, with pH (water) $5.7,6.6 \mathrm{~g} \mathrm{~kg}^{-1}$ of organic carbon, $8.0 \mathrm{mg} \mathrm{kg}^{-1}$ of $\mathrm{P}_{\text {resin }}, 9.6 \mathrm{mg} \mathrm{kg}^{-1}$ of N-NH $4,1.4 \mathrm{mg} \mathrm{kg}^{-1}$ of N-NO${ }_{3}^{-}, 608 \mathrm{mg} \mathrm{kg}{ }^{-1}$ of total nitrogen, $24 \mathrm{mmol}_{\mathrm{c}} \mathrm{kg}^{-1}$ of $\mathrm{H}+\mathrm{Al}, 16 \mathrm{mmol}_{\mathrm{c}} \mathrm{kg}^{-1} \mathrm{of} \mathrm{Ca}^{2+}$, $8 \mathrm{mmol}_{\mathrm{c}} \mathrm{kg}^{-1}$ of $\mathrm{Mg}^{2+}$ and $1.2 \mathrm{mmol}_{\mathrm{c}} \mathrm{kg}^{-1}$ of $\mathrm{K}$. The soil was fertilized with $40 \mathrm{mg} \mathrm{kg}^{-1}$ of $\mathrm{N}$ as ammonium nitrate, $160 \mathrm{mg} \mathrm{kg}^{-1}$ of $\mathrm{P}$ as triple superphosphate, $120 \mathrm{mg} \mathrm{kg}^{-1}$ of $\mathrm{K}$ as potassium chloride, $4 \mathrm{mg} \mathrm{kg}^{-1}$ of Cu as copper sulphate, $4 \mathrm{mg} \mathrm{kg}^{-1}$ of $\mathrm{Zn}$ as zinc sulphate, $0.8 \mathrm{mg} \mathrm{kg}^{-1}$ of Mo, as ammonium molybdate and $1.6 \mathrm{mg} \mathrm{kg}^{-1} \mathrm{of} \mathrm{B}^{-3}$ boric acid and transferred to bottom sealed, $8 \mathrm{dm}^{-3}$ polyethylene pots.

Twelve seeds of Congo grass (Brachiaria ruziziensis, Syn. Urochloa ruziziensis) were sown, and seven days after seedling emergence, they were thinned to four plants per pot. Soil water content was monitored daily and kept around $80 \%$ of the soil water retention capacity. There was no leaching. Forty-two days after emergence, the Congo grass plants were cut close to soil surface, and treatments were then installed: control (cotton grown in pots with no previous grass cultivation); whole plant residues (cotton grown in presence of the grass root and shoot residues); root residues (cotton grown in presence of the grass root residues). Shoot residues were chopped into pieces 3 to $5 \mathrm{~cm}$ long and accommodated on the soil surface. In pots without straw, the soil surface was covered with gray styrofoam flakes to avoid high temperatures and water loss. Five days after grass cutting, cotton (Gossypium hirsutum, var. Latifolia, cv. FMT 701) was planted and, after thinning, two plants were grown per pot. Congo grass root and shoot dry matter yields, and $\mathrm{C}$ and $\mathrm{N}$ contents were determined before cotton planting. Since this is a destructive sampling, eight replications were grown in excess, as previously described. The plants were cut close to soil surface, split into shoots and roots, and dried in a forced-air oven at $60^{\circ} \pm 2^{\circ} \mathrm{C}$ to constant mass. Then, the material was weighed, ground and analyzed for C (Alisson, 1965) and $\mathrm{N}$ contents, using wet digestion with sulfuric acid and distillation.

The treatments were arranged in a $3 \times 4$ factorial experimental design in complete randomized blocks, with four replications. The first factor was represented by three cotton cultivation systems (without Congo grass, whole plant residues and root residues), and the second factor was the application of four $\mathrm{N}$ rates $(0,50,100$ and 150 $\mathrm{mg} \mathrm{dm}$ ), as ammonium nitrate, at cotton planting.

Cotton plant height (from the soil surface to the apex of the plants) was measured at 5, 10, 15, 20, 25, 30 and 35 days after plant emergence (DAPE). Equations were fit to these data and growth rate was calculated using the first derivative of these equations. Chlorophyll readings were made using a SPAD meter (SPAD $502^{\circledR}$ Minolta) at 25 and 35 DAPE, on the fourth fully expanded leaf from the apex of the two plants in each pot. The plants were harvested at $45 \mathrm{DAPE}$, split into shoots and roots and dried in air-forced oven at $60 \pm 2^{\circ} \mathrm{C}$ to constant mass. The material was then weighed, ground and $\mathrm{N}$ contents determined by wet digestion and Kjeldahl distillation. When cotton was grown in presence of roots or whole plant residues, the proportion of roots of each species was estimated using stable carbon isotope fractioning $\left(\delta{ }^{13} \mathrm{C}\right)$. When there are only two isotopically distinct sources, the material $\delta{ }^{13} \mathrm{C}$ reflects the amount of each material in the mixture, which can be quantified by the following isotopic dilution equation: 


$$
\% \mathrm{C}_{4}=\left(\delta{ }^{13} \mathrm{C}_{\text {sample }}-\delta{ }^{13} \mathrm{C}_{4}\right) /\left(\delta{ }^{13} \mathrm{C}_{3}-\delta{ }^{13} \mathrm{C}_{4}\right)
$$

Where: $\delta^{13} \mathrm{C} 3$ and $\delta{ }^{13} \mathrm{C} 4$ are the isotopic composition of the $\mathrm{C} 3$ and $\mathrm{C} 4$ plant roots, respectively.

The isotopic composition of the root samples was determined in an isotopic ratio mass spectrometer (IRMS, Finnigan MAT Delta Plus). Samples were weighed and put in a tin capsule. After oxidation of the organic matter and chromatographic separation of the $\mathrm{CO}_{2}$ gas, it was conveyed to the spectrometer and the $\mathrm{C}$ isotopic concentrations were determined.

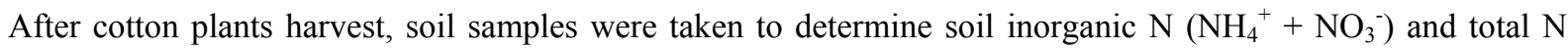
(Allison. 1965). In treatments in which the grass shoots remained on the soil surface, the amount of dry matter and remaining $\mathrm{N}$ were determined at the end of the cotton growth period. Straw decay and its $\mathrm{N}$ release were calculated.

The $\mathrm{N}$ balance in the soil-plant-straw system in the rotation Brachiaria-cotton was calculated after cotton harvest according to equation: Balance of $\mathrm{N}=$ [applied $\mathrm{N}+$ (initial soil inorganic $\mathrm{Ne}-$ final soil inorganic $\mathrm{Ne})-(\mathrm{N}$ accumulated in plants + remaining $\mathrm{N}$ in the grass residues)].

After ANOVA, treatment means were compared using the unpaired t-test $(\mathrm{P}<0.05)$, and regression equations were fit to $\mathrm{N}$ responses.

\section{Results}

The amount of Congo grass shoots present on the soil surface by the time cotton was planted was $26.0 \pm 3.0 \mathrm{~g}$ pot $^{-1}$ on average, equivalent to $6,842 \pm 790 \mathrm{~kg} \mathrm{ha}^{-1}$, with a $\mathrm{C} / \mathrm{N}$ ratio of $38.0 \pm 1.2$, which resulted in $273 \pm 17 \mathrm{mg}$ of $\mathrm{N} \mathrm{pot}^{-1}$. The amount of Congo grass root dry matter was $37.5 \pm 5.2 \mathrm{~g} \mathrm{pot}^{-1}$, with $6.9 \pm 0.7 \mathrm{~g} \mathrm{~kg}^{-1}$ of N , resulting in $254 \pm 15 \mathrm{mg}$ of $\mathrm{N} \mathrm{pot}^{-1}$, with a $\mathrm{C} / \mathrm{N}$ ratio of $45.0 \pm 3.0$.

During cotton growth (45 days), Congo grass straw on the soil surface decreased from 20 to $30 \%$ with application of zero and $120 \mathrm{mg} \mathrm{kg}^{-1}$ of $\mathrm{N}$, respectively (Table 1). From 19 to $28 \%$ of the $\mathrm{N}$ accumulated in the forage was released during decay, returning to the soil and increasing the amount of $\mathrm{N}$ available to cotton. However, regardless of the presence of straw on the soil surface, Congo grass root decay was not affected by $\mathrm{N}$ supply. The amount of remaining roots was approximately $33.5 \mathrm{~g} \mathrm{pot}^{-1}$, showing that, on average, only $10 \%$ was decomposed during cotton growth (Table 2). Forty-five days after Congo grass termination, by the time cotton was harvested, the Congo grass root proportion in the pots ranged from 62 to $75 \%$.

Table 1. Congo grass shoot dry matter and $\mathrm{N}$ contents, $\mathrm{N}$ released from the straw and $\mathrm{C} / \mathrm{N}$ ratio 45 days after cutting as affected by nitrogen fertilization

\begin{tabular}{ccccc}
\hline N rate & Dry matter & Remaining N & N released & C/N ratio \\
\hline $\mathrm{mg} \mathrm{kg}^{-1}$ & $\mathrm{~g} \mathrm{pot}^{-1}$ & $--------\mathrm{mg} \mathrm{pot}^{-1}$ & --------- & \\
0 & $20,9(20)^{(1)}$ & $221(19)^{(1)}$ & 52,3 & $32,0(15)^{(1)}$ \\
50 & $19,0(27)$ & $204(25)$ & 69,8 & $30,4(20)$ \\
100 & $19,2(26)$ & $202(26)$ & 71,7 & $29,9(21)$ \\
150 & $18,1(30)$ & $196(28)$ & 77,8 & $28,7(24)$ \\
\hline DMS & 2,0 & 25,2 & 7,4 & 3,1 \\
\hline
\end{tabular}

${ }^{(1)}$ Figures in parentheses show the relative (\%) decrease.

Table 2. Congo grass root dry matter 45 days after cutting as affected by residues and $\mathbf{N}$ application. Root dry matter was estimated from carbon stable isotope $\left(\delta^{13} \mathrm{C}\right)$ fractionation

\begin{tabular}{ccc}
\hline \multirow{2}{*}{$\mathrm{N}$ rate } & \multicolumn{2}{c}{ Residues } \\
\cline { 2 - 3 } & Roots & Whole plant \\
\hline $\mathrm{mg} \mathrm{kg}^{-1}$ & --------- g pot $^{-1}-------$ \\
0 & $34,0(9)^{(1)}$ & $33,0(12)$ \\
50 & $32,9(12)$ & $34,6(8)$ \\
100 & $33,9(10)$ & $33,6(10)$ \\
150 & $34,5(8)$ & $32,3(14)$ \\
\hline DMS & 4,0 & 3,9 \\
\hline
\end{tabular}

${ }^{(1)}$ Figures in parentheses show the relative (\%) decrease. 
Cotton growth was impaired in the presence of Congo grass residues, and responded to N application (Figure 1). Nitrogen fertilization increased cotton growth by $60 \%$ on average when residues were present, but there was no significant $(\mathrm{P}>0.05)$ response when there was no residue in the system. Accordingly, cotton plant dry matter yields were not affected by $\mathrm{N}$ rates in the absence of residues (Figure 2), but responded linearly up to $120 \mathrm{mg}$ $\mathrm{kg}^{-1}$ of $\mathrm{N}$ when in the presence either of Congo grass whole plants or roots (Figure 2). Cotton root dry matter yield was fully recovered when $\mathrm{N}$ was applied at $80 \mathrm{mg} \mathrm{kg}^{-1}$ in the presence of grass roots, but $120 \mathrm{mg} \mathrm{kg}^{-1}$ of $\mathrm{N}$ was required to overcome deleterious effects of Congo grass on cotton shoot growth.
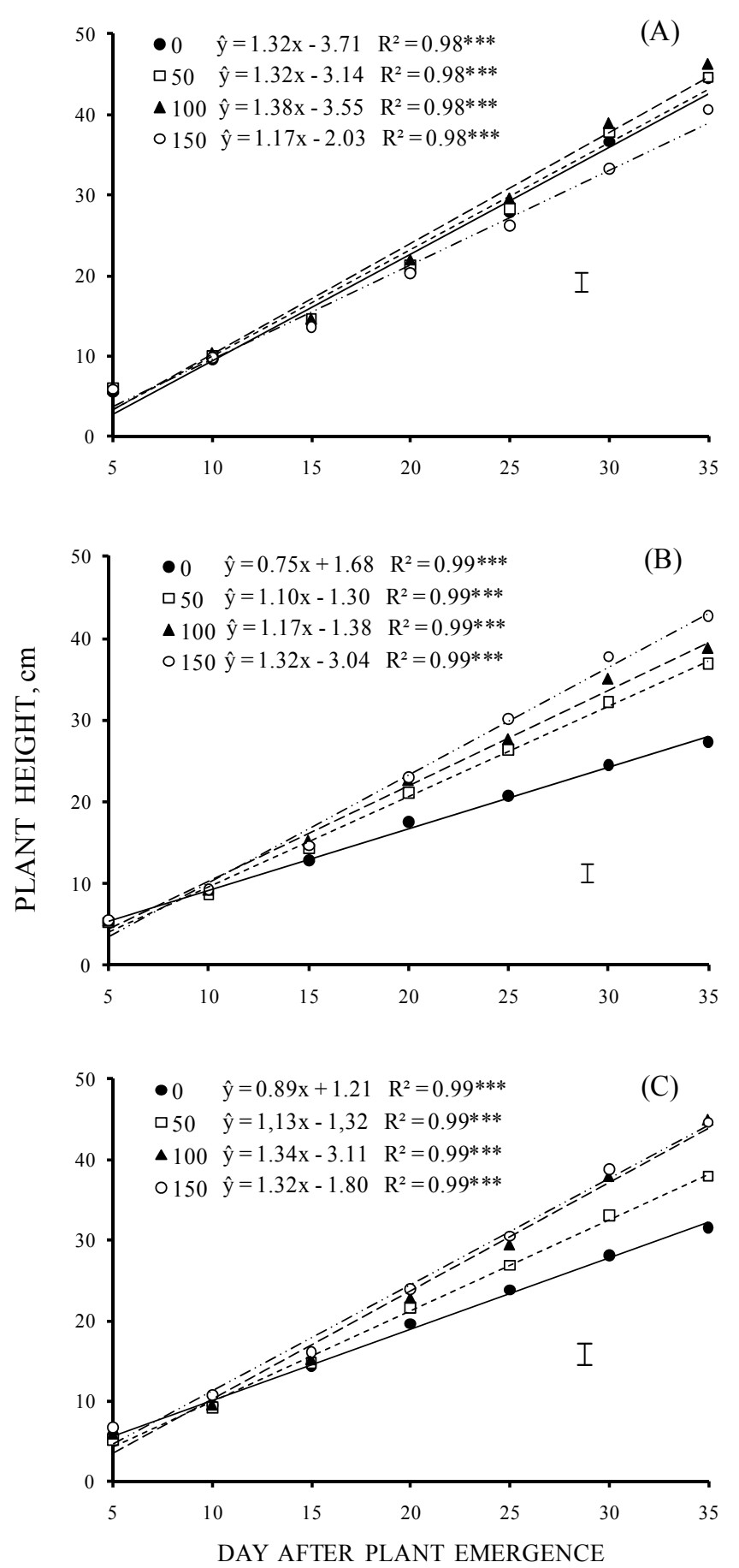

Figure 1. Cotton height in the absence (A), and in the presence of root residues (B) and whole plant residues (C) of Congo grass. No nitrogen supplied $(\bullet)$, with $50 \mathrm{mg} \mathrm{dm}^{-3}(\square), 100 \mathrm{mg} \mathrm{dm}^{-3}(\boldsymbol{\Delta})$ and $150 \mathrm{mg} \mathrm{dm}^{-3}(\circ)$ of $\mathrm{N}$. $* * *(\mathrm{P}<0.001)$. Vertical bars show LSD $(\mathrm{P}<0.05)$ 

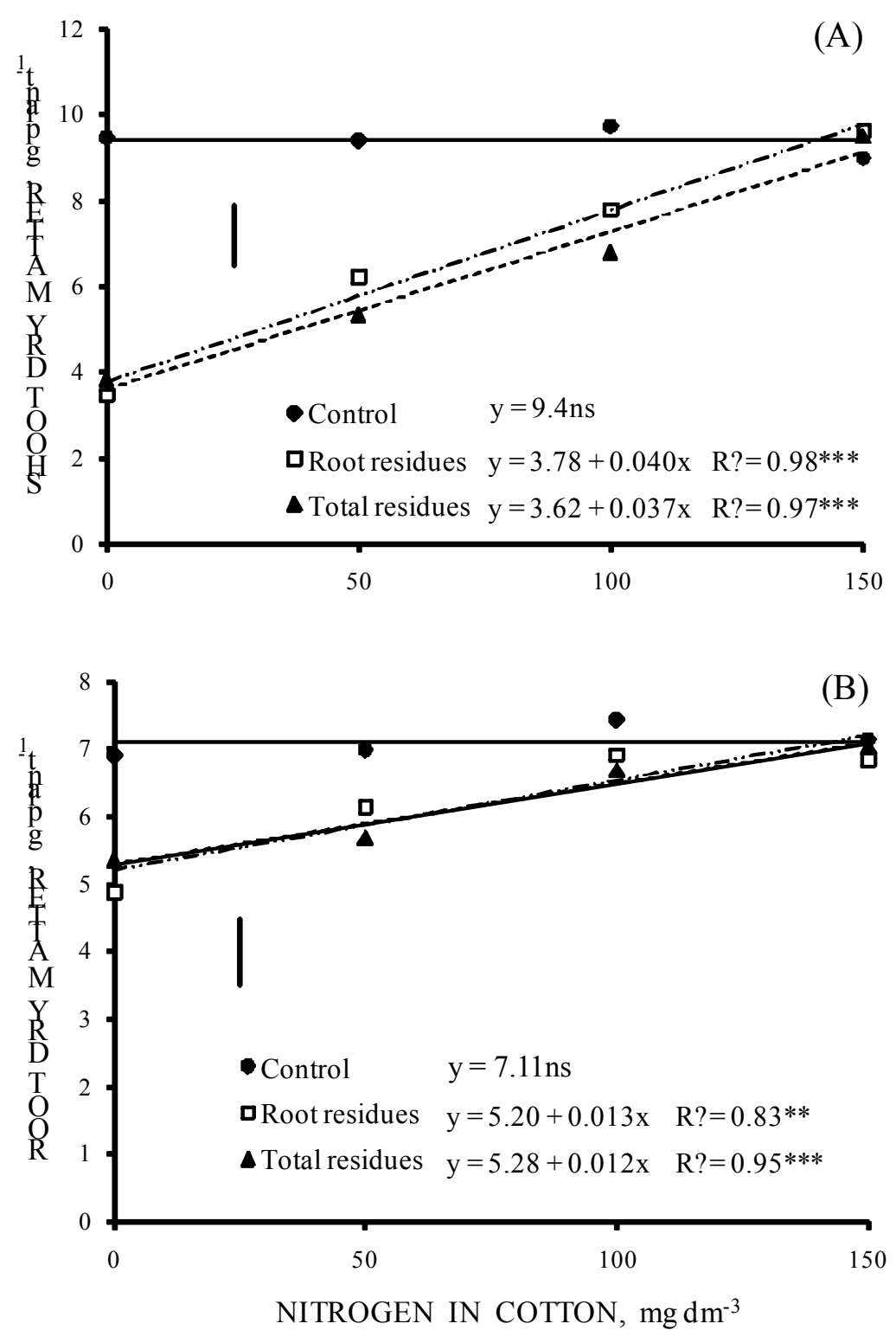

Figure 2. Cotton shoot (A) and root (B) dry matter in the absence (•) and presence of roots ( $\square$ ), and whole plant ( $\Delta$ ) Bacchiaria ruziziensis residues as affected by $\mathrm{N}$ application. ns: non-significant. ** $(\mathrm{P}<0.01)$, *** $(\mathrm{P}<0.001)$. Vertical bars shows LSD $(\mathrm{P}, 0.05)$

SPAD index was not affected by $\mathrm{N}$ fertilization in the absence of Congo grass residues, but increased linearly when the residues were present (Figure 3). Application of $120 \mathrm{mg} \mathrm{kg}^{-1}$ of $\mathrm{N}$ increased cotton plant SPAD index value to levels similar to those of control plants, even in the presence of Congo grass residues. 


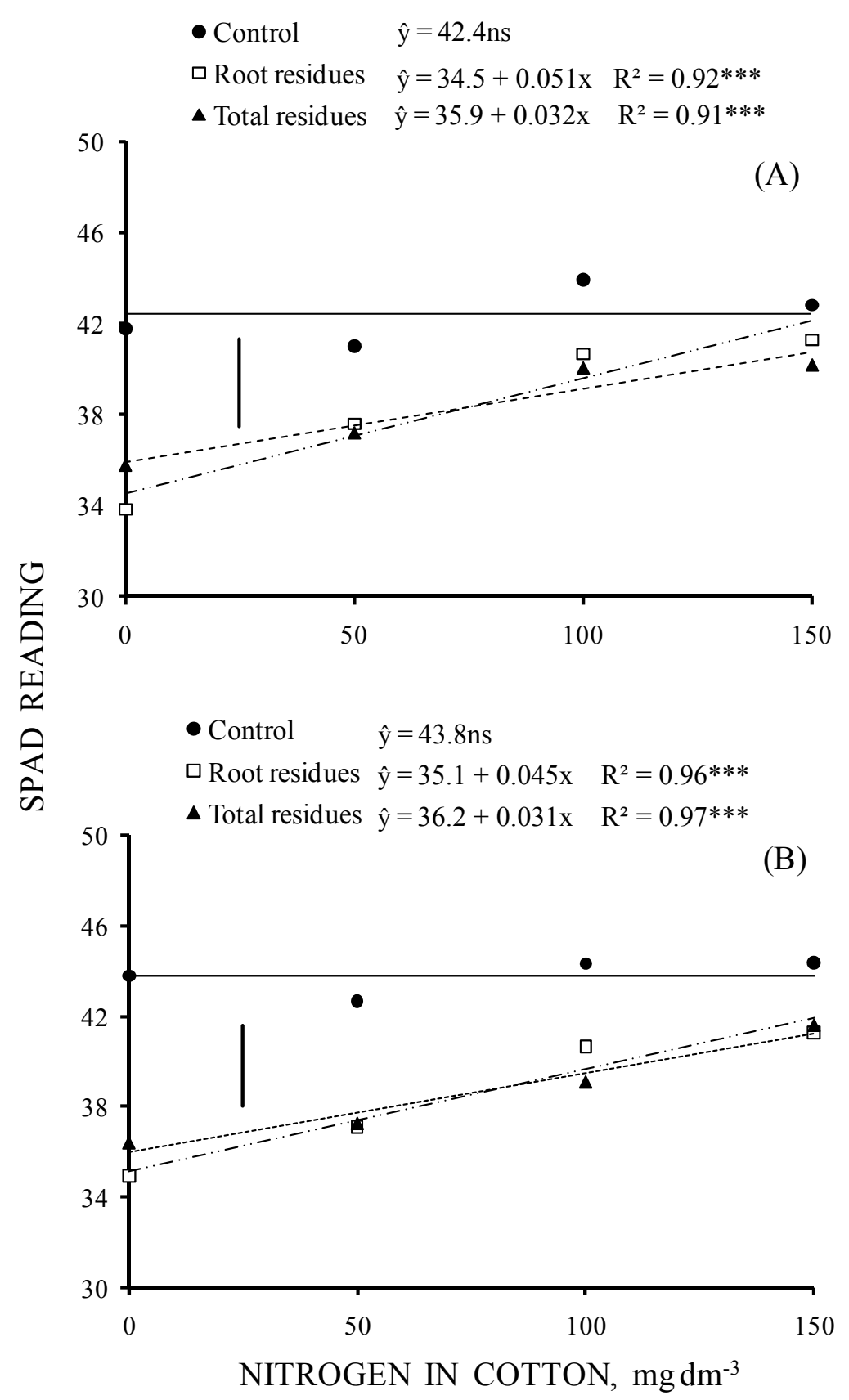

Figure 3. SPAD index at 25 (A) and 35 (B) days after plant emergence in cotton grown in the absence $(\bullet)$ and presence of root $(\square)$ and whole plant $(\boldsymbol{\Delta})$ Brachiaria ruziziensis residues, as affected by $\mathrm{N}$ application. ns: non-significant. ** $(\mathrm{P}<0.01), * * *(\mathrm{P}<0.001)$. Vertical bars shows LSD $(\mathrm{P}, 0.05)$.

Nitrogen contents in cotton increased with fertilizer rates (Figure 4A). However, these results may be just a "concentration effect", since the shoot dry matter yield was not affected (Figure 2A) in the absence of Congo grass residues. However, when grass residues were present, cotton shoot $\mathrm{N}$ concentrations were not affected by fertilizer application (Figure 4A), and the increase in $\mathrm{N}$ accumulation was due to the increase in shoot dry matter (Figure 2A). The accumulated amount of $\mathrm{N}$ in cotton shoots increased linearly with $\mathrm{N}$ rates (Figure 4B), but it was lower in treatments with residues. The content and accumulation of $\mathrm{N}$ in cotton grown after Congo grass without $\mathrm{N}$ fertilizer were 34 and $74 \%$ lower compared with that of the control, respectively. The lowest $\mathrm{N}$ accumulation in cotton shoots in the presence of residues was a result of the lowest dry matter yields (Figure 2A) and the lowest $\mathrm{N}$ content (Figure 4A). 


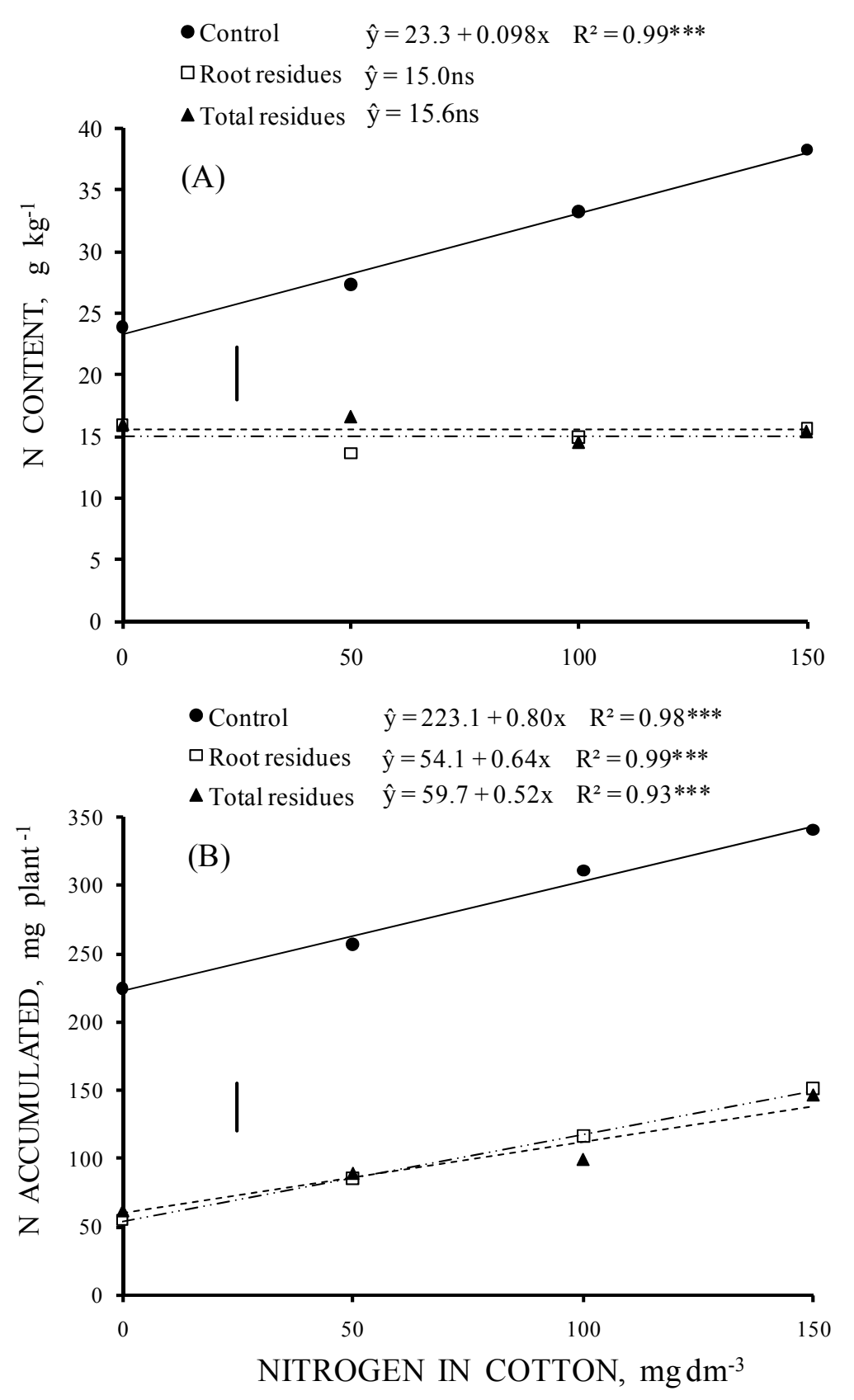

Figure 4. $\mathrm{N}$ concentrations (A) and accumulated N (B) in cotton shoots when grown in the absence (•) and presence of root ( $\square$ ) and whole plant $(\boldsymbol{\Delta})$ Brachiaria ruziensis residues as affected by $\mathrm{N}$ application. ns: non-significant. ** $(\mathrm{P}<0.01),{ }^{* * *}(\mathrm{P}<0.001)$. Vertical bars shows $\operatorname{LSD}(\mathrm{P}, 0.05)$

Nitrogen fertilizer application increased the soil inorganic $\mathrm{N}$ (Figure 5), and the lowest availability in the control treatment reflects the high amount of $\mathrm{N}$ taken up by the plants (Figure 4B). Total soil $\mathrm{N}$ content also responded to fertilization, but there was no significant difference with or without Congo grass residues (Table 3). In general, with 0.0 and $40 \mathrm{mg} \mathrm{kg}^{-1}$ of fertilizer- $\mathrm{N}$ total soil $\mathrm{N}$ decreased by the end of the experiment. Conversely, with application of 80 and $120 \mathrm{mg} \mathrm{kg}^{-1}$ of $\mathrm{N}$, there was an increase in soil total $\mathrm{N}$ (Table 3). Hence, when $\mathrm{N}$ availability is low the mineralization process exceeded immobilization, resulting in net mineralization, but the reverse occurred with the application of 80 and $120 \mathrm{mg} \mathrm{kg}^{-1}$ of $\mathrm{N}$. Consequently, the total $\mathrm{N}$ balance in the soil-plant-straw system (Figure 5) was negative under low $\mathrm{N}$ availability, but was positive with the application of 80 and $120 \mathrm{mg} \mathrm{kg}^{-1}$ of $\mathrm{N}$. 

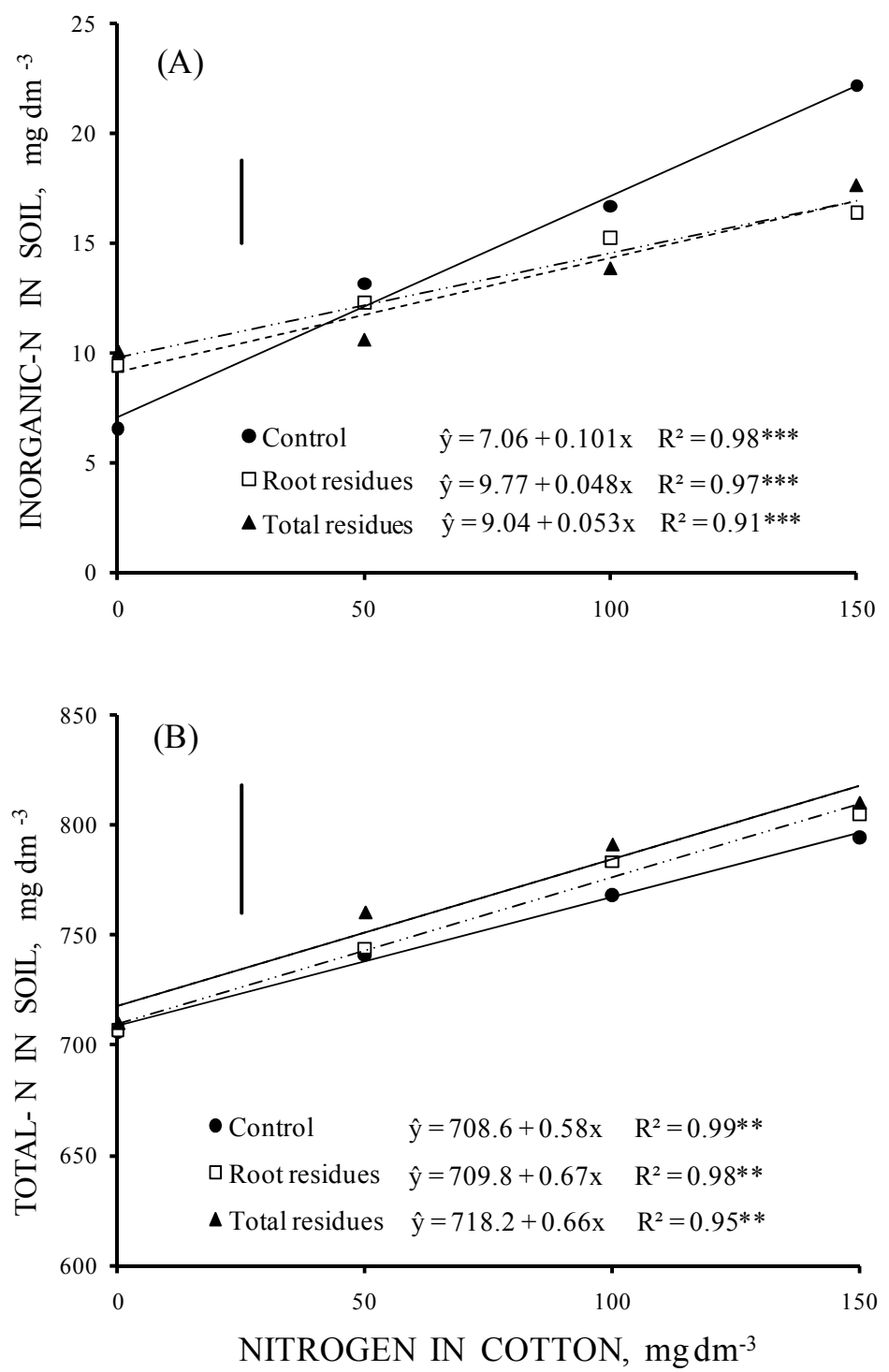

Figure 5. Soil inorganic (A) and total N (B) after cotton harvest in the absence $(\bullet)$ and presence of root ( $\square$ ) and whole plant ( $\boldsymbol{\Lambda}$ ) Brachiaria ruziensis residues as affected by $\mathrm{N}$ application. ns: non-significant. ** $(\mathrm{P}<0.01)$, $* * *(\mathrm{P}<0.001)$. Vertical bars shows LSD $(\mathrm{P}, 0.05)$

\section{Discussion}

The average $\mathrm{C} / \mathrm{N}$ ratio of 38 for Congo grass straw at cutting is within the expected values ranging from 35 to 40 for a number of grasses used as cover crops (Torres, Pereira, Andrioli, Polidoro, \& Fabian, 2005). The magnitude of the $\mathrm{C} / \mathrm{N}$ ratio affects the decomposing rate and eventually the release of $\mathrm{N}$ (Nicolardot et al., 2001), and nitrogen application decreased the residue $\mathrm{C} / \mathrm{N}$ ratio by 15 to $24 \%$ (Table 1), which resulted in higher $\mathrm{N}$ availability within the system and increased residue decay rates. It had already been observed that $\mathrm{N}$ fertilization can decrease $\mathrm{C} / \mathrm{N}$ ratio in grasses (Rosolem et al. 2004) and increase the straw decomposition rate, as occurred in the present experiment. A linear relationship was obtained between the amount of $\mathrm{N}$ mineralized and the initial organic $\mathrm{N}$ content of the residue, and the correlation was less significant for the roots than for the leaves or stems (Abiven et al., 2005). Therefore, the low residue decomposition (Tables 1 and 2) could be due to the high shoot and root $\mathrm{C} / \mathrm{N}$ ratios of value 38 and 45 , respectively. It was also observed in the present study, that mineralization rate of root $\mathrm{C}$ was significantly lower than that of leaves and stems (Urquiaga et al., 1998; Abiven et al., 2005). It has been accepted that the dry matter decay and release of compounds from plant roots are slower than rest of the plant parts because there is fewer decomposing microorganisms in the roots (Jawson \& Elliot, 1986). Besides, recalcitrant materials such as grass roots, with high lignin-suberin content (Abiven et al., 2005) lead to a larger diversity of decomposers compared with easily degradable materials (Lindedam, Magid, Poulsin, 
\& Luxshoi, 2009). Furthermore, when the residues are left on the soil surface, as it was the case for brachiaria shoots in this experiment, the decomposition rate is lower than when it is incorporated (Abiven \& Recous, 2007).

Allelopathic effects of forage grasses, mainly shoots, have been reported on several crops, such as soybean (Olibone et al., 2006), cotton, rice, beans, corn, soybean and wheat (Souza et al., 2006). However, such effect can be disregarded in the present study, since cotton growth was similar either in the presence of root residues only or in the presence of root plus shoot residues (Figure 1). If there had been any allelopathic effect, the presence of whole plant residues (shoot + root) would have reduced cotton growth compared with sole roots, because they were shown to be more expressive in the presence of shoot residues (Correia et al., 2005; Olibone et al., 2006).

In systems with high amounts of high $\mathrm{C} / \mathrm{N}$ ratio residues, it is generally necessary to add a greater amount of $\mathrm{N}$ fertilizer to reach economically sound yields (Rosolem et al., 2004). In the present study, it was necessary to apply $120 \mathrm{mg} \mathrm{kg}^{-1}$ of $\mathrm{N}$ to neutralize the negative residue effects (Figure 2A). According to Vaughan and Evanylo (1998), the amount of supplementary $\mathrm{N}$ needed varies according to the amount of plant residues, the residue chemistry and the period between cover crop termination and planting of the subsequent crop.

Maintenance of cover crop residues on the soil surface increases microbial immobilization of $\mathrm{N}$ in the initial stages of decomposition (Vaughan \& Evanylo, 1998; Malhi, Grant, Johnston, \& Gill, K. S. 2001; Rosolem, Foloni, \& Oliveira, 2003), which happened in the present experiment, where the presence of Congo grass shoot residues resulted in greater immobilization of soil $\mathrm{N}$ in the presence of fertilizer (Figure 5). Although much attention has been paid to the effects of soil surface straw on soil $\mathrm{N}$ dynamics and availability (Silva \& Rosolem, 2001; Abiven \& Recous, 2007; Rosolem et al., 2004; Torres et al., 2005), in this experiment the presence of Congo grass root residues alone was as harmful for cotton growth as the presence of whole plant residues (roots + shoots). Therefore, grasses with root residues with high $\mathrm{C} / \mathrm{N}$ ratios and high lignin contents as Congo grass may lead to significant decreases in soil $\mathrm{N}$ availability. This is particularly true in cropping systems where cover crops with vigorous, extensive and deep root systems are used, as recommended in tropical regions (Calonego \& Rosolem, 2010).

A decrease in the amount of nutrient present in soil shows that the added fertilizer was not enough to meet plant demand and immobilize in the soil. In this study, when $\mathrm{N}$ availability was low $\left(0 \mathrm{mg} \mathrm{kg}^{-1}\right.$ of $\left.\mathrm{N}\right)$, total soil $\mathrm{N}$ that was originally $608 \mathrm{mg} \mathrm{kg}^{-1}$ decreased by the end of the experiment (Figure 5). This result shows that cotton depended on the soil organic $\mathrm{N}$ to meet its nutritional requirement, and eventually the balance of inorganic $\mathrm{N}$ in the soil-plant-straw system was negative. Conversely, by raising $\mathrm{N}$ doses, the immobilization process exceeded the mineralization process, resulting in net immobilization and positive balance of $\mathrm{N}$ in the soil (Figure 6).

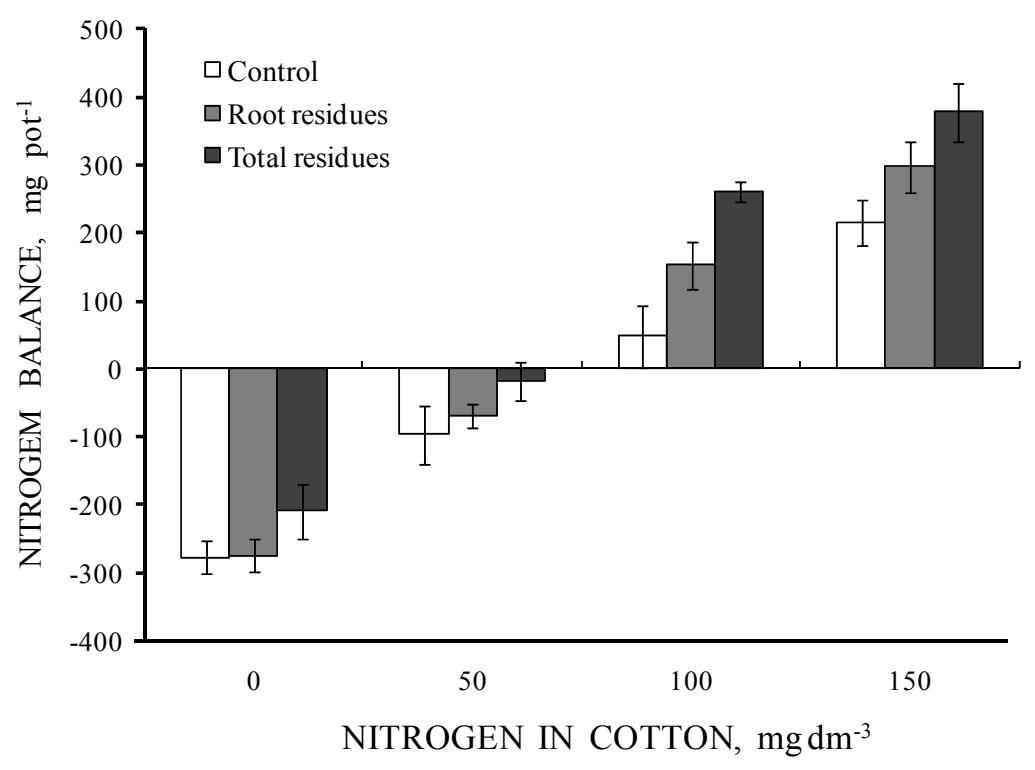

Figure 6. Nitrogen balance in the soil [applied $\mathrm{N}+$ (initial soil inorganic $\mathrm{N}-$ final soil inorganic $\mathrm{N}$ ) $-\mathrm{N}$ in cotton and Bracchiria ruziziensis shoots) either in absence or in presence of B.ruziziensis roots and whole plant residues, as affected by $\mathrm{N}$ application. Vertical bars show means $(\mathrm{n}=4) \pm$ standard error 
The carbon $(\mathrm{C})$ stable isotope $\left(\delta{ }^{13} \mathrm{C}\right)$ fractionation method was very effective to separate roots of $\mathrm{C} 3$ (cotton) and $\mathrm{C} 4$ (Congo grass) plant root residues in the soil.

The presence of plant residues with $\mathrm{C} / \mathrm{N}$ ratio over 30 in soil has been one of the main causes of low yields in crop rotations, mainly as a result of soil $\mathrm{N}$ immobilization, at least temporarily (Nicolardot et al., 2001). Therefore, it can be inferred that the high $\mathrm{C} / \mathrm{N}$ ratio and low decay rate of Congo grass root residues immobilized soil $\mathrm{N}$, which resulted in lower $\mathrm{N}$ uptake by cotton and lower dry matter yields (Fig 2). This is supported by the lower SPAD index (Fig 3) showing N deficiency (Rosolem \& Mellis, 2010) and the lower N accumulation in the shoots (Figure 4) observed in the presence of brachiaria residues. Given time, the N immobilized will be mineralized and available (Mary, Recous, Darwis, \& Robin, 1996), but this would be too late, because cotton responds better to $\mathrm{N}$ applied up to 50-55 days after plant emergence.

\section{Conclusion}

In general, the results of the present experiment confirm the hypothesis that the presence of Congo grass root residues, due to their slow decay rate, high suberin/lignin contents and high $\mathrm{C} / \mathrm{N}$ ratio, leads to the immobilization of $\mathrm{N}$ in the system, at least temporarily. This competition results in lower $\mathrm{N}$ absorption and lower cotton yields. The effects of surface straw on $\mathrm{N}$ availability in no-till systems has been studied and generally accepted. However, findings of the present experiment highlight the great importance of cover crop roots on soil $\mathrm{N}$ dynamics and availability, mainly in agricultural production systems in which species with aggressive root systems with long persistence in the soil, as is the case of the forage grasses of the genre Brachiaria spp, are used. In this case, $\mathrm{N}$ fertilizer application compensated for the nutrient immobilization so that plants show normal growth in the presence of grass residues.

\section{References}

Abiven, S., \& Recous, S. (2007). Mineralisation of crop residues on the soil surface or incorporated in the soil under controlled conditions. Biol. Fertil. Soils, 43, 849-852. http://dx.doi.org/10.1007/s00374-007-0165-2

Abiven, S., Recous, S., Reyes, V., \& Oliver, R. (2005). Mineralisation of C and N from root, stem and leaf residues in soil and role of their biochemical quality. Biol. Fertil. Soils, 42, 119-128. http://dx.doi.org/10.1007/s00374-005-0006-0

Allison, L. E. (1965). Organic carbon. In C. A. Black, D. D. Evans, L. E. Ensminger, J. L. White, J. L., \& F. E. Clark (Ed.), Methods of soil analysis (Vol. 2, pp. 1367-1379). Madison, USA: American Society for Agronomy.

Allison, L. E. (1966). The fate of nitrogen applied to soils. Adv. Agron., 18, 219-258. http://dx.doi.org/10.1016/S0065-2113(08)60651-3

Boutton, T. W. (1991). Stable carbon isotope ratios of natural materials: II. Atmospheric, terrestrial, marine, and freshwater environments. In D.C. Coleman \& B. Fry (Ed.), Carbon Isotope Techniques (pp. 173-185). New York, USA: Academic Press.

Calonego, J. C., \& Rosolem, C. A. (2010). Soybean root growth and yield in rotation with cover crops under chiseling and no-till. European Journal of Agronomy, 33, 242-249. http://dx.doi.org/10.1016/j.eja.2010.06.002

Correia, N. M., Centurion, M. A. P. C., \& Alves, P. L. C. A. (2005). Influência de extratos aquosos de sorgo sobre a germinação e desenvolvimento de plântulas de soja. Ci. Rural, 35, 498-503. http://dx.doi.org/10.1590/S0103-84782005000300002

Jawson, M. D., \& Elliott, L. F. (1986). Carbon and nitrogen transformations during wheat straw and root decomposition. Soil Biology and Biochemistry, 18, 15-22. http://dx.doi.org/10.1016/0038-0717(86)90097-0

Lindedam, J., Magid, J., Poulsin, P., \& Luxshoi, J. (2009). Tissue architecture and soil fertility controls on decomposer communities and decomposition of roots. Soil Biology \& Biochemistry, 41, 1040-1049. http://dx.doi.org/10.1016/j.soilbio.2009.01.023

Malhi, S. S., Grant, C. A., Johnston, A. M., \& Gill, K. S. (2001). Nitrogen fertilization management for no-till cereal production in the Canadian Great Plains: a review. Soil Till. Res., 60, 101-122. http://dx.doi.org/10.1016/S0167-1987(01)00176-3

Mary, B., Recous, S., Darwis, D., \& Robin, D. (1996). Interactions between decomposition of plant residues and nitrogen cycling in soil. Plant Soil, 181, 71-82. http://dx.doi.org/10.1007/BF00011294 
Nicolardot, B., Recous, S., \& Mary, B. (2001). Simulation of C and N mineralization during crop residue decomposition: A simple dynamic model based on the $\mathrm{C} / \mathrm{N}$ ratio of the residues. Plant Soil, 228, 83-103. http://dx.doi.org/10.1023/A:1004813801728

Olibone, D., Calonego, J. C., Pavinato, P. S., \& Rosolem, C. A. (2006). Crescimento inicial da soja sob efeito de resíduos de sorgo. Planta Daninha, 24, 255-261. http://dx.doi.org/10.1590/S0100-83582006000200007

Rezende, C. P., Cantarutti, R. B., Braga, J. M., Gomide, J. A., Pereira, J. M., Ferreira, E., ... Boddey, R. M. (1999). Litter deposition and disappearance in Brachiaria pastures in the Atlantic forest region of the South of Bahia, Brazil. Nutrient Cycling in Agroecosystems, 54, 99-112. http://dx.doi.org/10.1023/A:1009797419216

Rosolem, C. A., \& Mellis, V. (2010). Monitoring nitrogen nutrition in cotton. R. Bras. Ci. Solo, 34, 1601-1607. http://dx.doi.org/10.1590/S0100-06832010000500013

Rosolem, C. A., Foloni, J. S. S., \& Oliveira, R. H. (2003). Dinâmica do nitrogênio no solo em razão da calagem e adubação nitrogenada, com palha na superfície. Pesq. Agropec. Bras., 38, 301-309. http://dx.doi.org/10.1590/S0100-204X2003000200018

Rosolem, C. A., Pace, L., \& Crusciol, C. A. C. (2004). Nitrogen management in maize cover crop rotations. Plant and Soil, 264, 261-271. http://dx.doi.org/10.1023/B:PLSO.0000047761.50641.a3

Silva, R. H., \& Rosolem, C. A. (2001). Influência da cultura anterior e da compactação do solo na absorção de

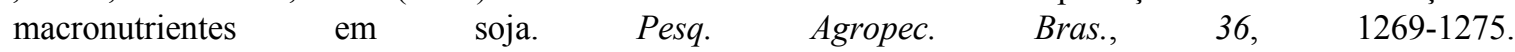
http://dx.doi.org/10.1590/S0100-204X2001001000009

Soil Survey Staff. (2010). Keys to soil taxonomy. USDA, Washington

Souza, L. S., Velini, E. D., Martins, D., \& Rosolem, C. A. (2006). Efeito alelopático de capim-braquiária (Brachiaria decumbens) sobre o crescimento inicial de sete espécies de plantas cultivadas. Planta Daninha, 24, 657 668. http://dx.doi.org/10.1590/S0100-83582006000400006

Torres, J. L. R., Pereira, M. G., Andrioli, I., Polidoro, J. C., \& Fabian, A. J. (2005). Decomposição e liberação de nitrogênio de resíduos culturais de plantas de cobertura em um solo de cerrado. Revista Brasileira de Ciência do Solo, 29, 609-618. http://dx.doi.org/10.1590/S0100-06832005000400013

Trinsoutrot, I., Recous, S., Bentz, B., Linères, M., Chèneby, D., \& Nicolardot, B. (2000). Biochemical quality of crop residues and carbon and nitrogen mineralization kinetics under non limiting nitrogen conditions. Soil Sci.l Soc. Am. J., 64, 918-926. http://dx.doi.org/10.2136/sssaj2000.643918x

Urquiaga, S., Cadish, G., Alves, B. J. R., Boddey, R., \& Giller, K. E. (1988). Influence of decomposition of roots of tropical forage species on the availability of soil nitrogen. Soil Biol. Biochem., 30, 2099-2106. http://dx.doi.org/10.1016/S0038-0717(98)00086-8

Vaughan, J. D., \& Evanylo, G. K. (1998). Corn response to cover crop species, spring desiccation time, and $\begin{array}{lllll}\text { residue } \quad \text { Agron. } & \text { management. }\end{array}$ http://dx.doi.org/10.2134/agronj1998.00021962009000040016x 